Riwayat draf artikel Diserahkan 10-09-2021 Direvisi 12-10-2021 Diterima 13-10-2021 Publish 20-10-2021

\section{Analisis Penerapan Media Pembelajaran berbasis E-Lumak pada Mata Kuliah Statistik Pendidikan PG-PAUD UM Kendari}

\author{
Usman $^{1^{*}}$, Arfin $^{2}$, Roni Amaludin ${ }^{3}$, Nurlina $^{4}$, Risnajayanti $^{5}$ \\ PG-PAUD, Universitas Muhammadiyah Kendari ${ }^{1345}$ \\ Administrasi Pendidikan, Universitas Muhammadiyah \\ Kendari ${ }^{2}$ \\ Email: usman@umkendari.ac.id
}

\begin{abstract}
ABSTRAK: Tujuan penelitian untuk menganalisis penerapan media e-lumak dalam pembelajaran statistik pendidikan pada mahasiswa PG-PAUD. Jenis penelitian ini adalah deskriptif kualitatif. Tempat dan waktu penelitian dilaksanakan di Universitas Muhammadiyah Kendari pada mahasiswa yang memprogramkan mata kuliah statistik Pendidikan Tahun Ajaran 2020/2021. Subjek dalam penelitian ini adalah mahasiswa dan dosen pengampu matakuliah statistik pendidikan. Teknik pengumpulan data melalui observasi, wawancara, dan dokumentasi. Teknik analisis data terdiri dari reduksi data, penyajian data, dan penarikan kesimpulan. Berdasarkan hasil penelitin maka dapat disimpulkan sebagai berikut: (1) Media elumak sudah cukup baik dalam pembelajaran online pada mata kuliah statistik pendidikan di masa pandemi covid-19. Terdapat tiga tahapan dalam pembelajaran melalui media e-lumak antara lain tahap perencanaan, tahap pelaksanaan, dan tahap evaluasi; (2) Kelebihan penerapan media e-lumak adalah fitur-fitur yang sangat kompleks. Kekurangan media e-lumak adalah server kurang stabil.
\end{abstract}

Kata Kunci: E-lumak, Media Pembelajaran, Statistik Pendidikan.

ABSTRACT: The purpose of the study was to analyze the application of e-lumak media in teaching educational statistics to PG-PAUD students. This type of research is descriptive qualitative. The place and time of the research was carried out at the University of Muhammadiyah Kendari for students who programmed the Education Statistics course for the 2020/2021 Academic Year. The subjects in this study were students and lecturers in education statistics courses. Data collection techniques through observation, interviews, and documentation. Data analysis techniques consist of data reduction, data presentation, and drawing conclusions. Based on the research results, it can be concluded as follows: (1) e-lumak media is quite good in online learning in educational statistics courses during the covid-19 pandemic. There are three stages in learning through e-lumak media, including the planning stage, implementation stage, and evaluation stage; (2) The advantages of implementing $e$ lumak media are very complex features. The drawback of e-lubricant media is that the server is less stable.

Keywords: E-lumak, Learning Media, Education Statistics

\title{
PENDAHULUAN
}

Masa pandemi Covid-19 adalah masa dimana Covid-19 yang menular di seluruh dunia dan mematikan sehingga membatasi kehidupan sosial masyarakat (Nasir et al., 2020). Menurut World Health Organizaton (2020), pada Desember 2019, kasus pneumonia misterius pertama kali dilaporkan di Wuhan, Provinsi Hubei. Sumber penularan kasus ini masih belum diketahui past, tetapi kasus pertama dikaitkan dengan pasar ikan di Wuhan. Tanggal 18 Desember hingga 29 Desember 2019, terdapat lima pasien yang dirawat dengan Acute Respiratory 
Distress Syndrome (ARDS). Teknologi memiliki banyak manfaat dalam dunia Pendidikan pada masa pandemi covid-19.

Surjono (2011), globalisasi semakin terus membawa perubahan pada segala lini kehidupan yang menuntut manusia harus mampu mengikuti arusnya, seperti dalam bidang pendidikan, sosial, ekonomi, hukum, politik, IPTEK dan lain-lain. Pengaruh globalisasi yang membawa perubahan positif pada salah satu bidang IPTEK yaitu dengan meningkatnya kemajuan ilmu pengetahuan dan teknologi. Kemajuan ilmu pengetahuan dan teknologi sekarang ini membawa pengaruh pada bidang pendidikan salah satunya dalam hal penggunaan alat-alat bantu, dan sarana pembelajaran yang berbeda di sekolah dan lembaga pendidikan yang digunakan oleh guru dalam menunjang proses pembelajaran. Semakin pesatnya kemajuan IPTEK inilah yang menuntut sekolah dan lembaga pendidikan untuk mengikuti perubahan salah satunya dalam penggunaan dan pemanfaatan media pembelajaran.

Menurut Wijaya (2012), media Pembelajaran merupakan komponen yang memiliki peran penting dalam menunjang keberhasilan pembelajaran. Media pembelajaran berperan sebagai sarana atau alat bantu penyalur yang digunakan oleh guru dan berperan sebagai fasilitator dalam proses pembelajaran untuk menyampaikan materi pelajaran kepada peserta didik. Proses pembelajaran di masa pandemi covid-19 hanya mampu mengukur dua aspek yaitu kognitif dan psikomotorik. Aspek afektif tidak mampu dinilai oleh seorang dosen. Hal ini dikarenakan antara dosen dan mahasiswa tidak saling bertatap muka secara langsung. Oleh karena itu, tatanan dunia pendidikan berubah secara signifikan. Salah satu bentuk pengintegrasian TIK dalam pembelajaran adalah pembelajaran berbasis elektronik menggunakan internet (e-learning). Penerapan e-learning sebagai bagian integral dari sistem pembelajaran telah dilakukan oleh beberapa lembaga pendidikan di berbagai negara, seperti Jerman, Italia, Amerika Serikat, Inggris, Perancis, Singapura, termasuk juga Indonesia (Wena, 2009).

Perancangan media pembelajaran sangat penting pada masa pandemi covid-19. Seluruh dosen pada Universitas Muhammadiyah Kendari diberikan pembekalan mengenai platform media pembelajaran online. Platform yang digunakan oleh Universitas Muhammadiyah Kendari adalah E-lumak. Pada semester genap tahun ajaran 2019/2020 jumlah dosen yang menggunakn media e-lumak hanya sebagian kecil. Hal ini dikarenakan kurangnya pemahaman dosen tentang media tersebut. Oleh karena itu, pihak Universitas Muhammadiyah Kendari pada bulan Juli 2020 membekali seluruh dosen tentang e-lumak dengan tujuan pada semester Ganjil tahun ajaran 2020/2021 seluruh dosen menggunakan media e-lumak atau lebih dikenal dengan SPADA.

Matakuliah statistik pendidikan merupakan matakuliah yang memerlukan pemahaman tinggi pada mahasiswa. Hal ini disebabkan konten matakuliah ini berisi pemahaman konsep, pemahan rumus, dan aplikasi dari rumus tersebut. Sehingga ini menjadi tantangan bagi dosen untuk merancang pembelajaran berbasis online dengan menggunakan media pembelajaran e-lumak agar mahasiswa dapat dengan mudah memahami capain matakuliah. Berdasarkan 
pengalaman peneliti pada tahun 2017, 2018, dan 2019 pada mahasiswa program studi PG-PAUD yang memprogramkan matakuliah statistik Pendidikan mengalami banyak kendala diantaranya adalah kurangnya kemampuan dasar mahasiswa terkait dengan matematika.

Purwandani (2016) mengemukakan pemilihan media pembelajaran sangat berpengaruh pemahaman mahasiswa pada matakuliah statistik Pendidikan. Proses pembelajaran dimasa covid-19 dilakukan tanpa bertatap muka atau pembelajaran secara online. Pelaksanaan perkuliahan pada semester Genap tahun ajaran 2019/2020 dosen menggunakan media yang beragam antara lain zoom meeting, geogle meet, lark, webex, cloudx telkomesel, geogle classroom, dan whatsapp. Namun, Universitas Muhammadiyah Kendari menggunakan platform sendiri dalam pelaksanaan perkuliahan pada semester Ganjil tahun ajaran 2020/2021 menggunakan media e-lumak atau SPADA UM Kendari.

Tujuan penelitian ini adalah untuk mendeskripsikan dan menganalisis: (1) Penerapan media pembelajaran berbasis e-lumak dalam pembelajaran statistik pendidikan pada mahasiswa PG-PAUD UM Kendari di Masa Pandemi Covid-19. (2) Kelebihan dan kekurangan penerapan media pembelajaran berbasis e-lumak dalam pembelajaran statistik pendidikan pada mahasiswa PG-PAUD UM Kendari di Masa Pandemi Covid-19.

Mahnun (2012) menyebutkan bahwa "media" berasal dari bahasa Latin "medium" yang berarti "perantara" atau "pengantar" Media pembelajaran adalah suatu alat yang digunakan oleh pengajar (dosen) untuk mentransfer informasi kepada mahasiswa. Menurut Chandrawati (2010) media merupakan salah satu komponen komunikasi, yaitu sebagai pembawa pesan dari komunikator menuju komunikan. Berdasarkan definisi tersebut, dapat dikatakan bahwa proses pembelajaran merupakan proses komunikasi. Senada dengan apa yang dikatakan oleh Hamalik (1994), bahwa media pembelajaran adalah salah satu alat bantu mengajar bagi guru untuk menyampaikan materi pengajaran, meningkatkan kreatifitas siswa dan meningkatkan perhatian mahasiswa dalam proses pembelajaran

Herayanti (2017), menyatakan bahwa fungsi media pembelajaran dalam proses pembelajaran, di mana media memiliki fungsi sebagai pembawa informasi dari sumber (dosen) menuju penerima (mahasiswa). Sedangkan metode adalah prosedur untuk membantu siswa dalam menerima dan mengolah informasi guna mencapai tujuan pembelajaran. Fungsi media dalam proses pembelajaran ditunjukkan pada Gambar 1 berikut: 


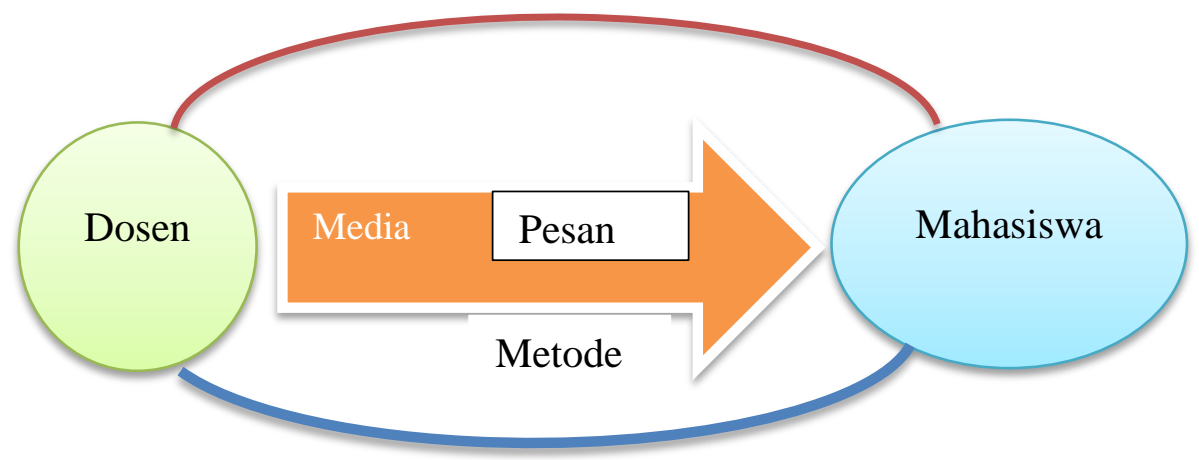

Gambar 1. Fungsi Media dalam Proses Pembelajaran (Herayanti, 2017)

Fungsi Media dalam Proses Pembelajaran Dalam kegiatan interaksi antara mahasiswa dengan lingkungan, fungsi media dapat diketahui berdasarkan adanya kelebihan media dan hambatan yang mungkin timbul dalam proses pembelajaran.

Bambang (2011), model pembelajaran berbasis TIK dengan menggunakan e-learning berakibat pada perubahan budaya belajar dalam konteks pembelajarannya. Setidaknya ada empat komponen penting dalam membangun budaya belajar dengan menggunakan model e-learning di sekolah. Pertama, siswa dituntut secara mandiri dalam belajar dengan berbagai pendekatan yang sesuai agar siswa mampu mengarahkan, memotivasi, mengatur dirinya sendiri dalam pembelajaran. Kedua, guru mampu mengembangkan pengetahuan dan ketrampilan, memfasilitasi dalam pembelajaran, memahami belajar dan hal-hal yang dibutuhkan dalam pembelajaran. Ketiga tersedianya infrastruktur yang memadai dan yang ke empat administrator yang kreatif serta penyiapan infrastrukur dalam memfasilitasi pembelajaran.

Sukardi \& Rozi (2019), Integrasi teknologi yang meningkat dengan cepat telah membawa perubahan yang kuat pada sistem pendidikan dan meningkatkan keterampilan digital baik mahasiswa maupun dosen. Teknologi juga dapat mempengaruhi cara berpikir, belajar, dan berinteraksi.

Siahaan (2003), salah satu pemanfaatan internet dalam dunia Pendidikan adalah pembelajaran dalam jaringan (on-line). Terdapat berbagai istilah untuk mengemukakan gagasan mengenai pembelajaran online dengan menggunakan internet yaitu on-line learning, e-learning, internet-enabled, virtual learning, virtual classroom atau web based learning. Penelitian ini menggunakan pembelajaran e-lumak atau virtual learning.

Purmono (2014) menyatakan bahwa e-learning menyediakan konten yang dibutuhkan untuk pembelajaran. Hampir semua mahasiswa memiliki laptop/smartphone/tablet, sehingga akses terhadap materi belajar semakin mudah dan sangat memungkinan bagi mahasiswa untuk saling berbagi konten pembelajaran melalui perangkat elektronik. Kondisi seperti ini membuat konten pembelajaran semakin lebih cepat didapatkan. 


\section{METODE PENELITIAN}

Metode penelitian penelitian ini adalah metode kualitatif deskriptif. Satori \& Komariah (2011) menjelaskan bahwa penelitian deskriptif berusaha untuk mendiskripsikan suatu objek, fenomena, atau setting sosial diterjemahkan dalam suatu tulisan yang bersifat naratif. Moleong (2007) menjelaskan bahwa dalam penelitian kualittif data, fakta yang dihimpun berbentuk kata atau gambar dari adanya angka-angka. Mendiskripsikan sesuatu berarti menggambarkan apa, mengapa dan bagaimana suatu kejadian terjadi.

Tempat penelitian dilakukan di program studi Pendidikan Guru Pendidikan Anak Usia Dini Fakultas Keguruan dan Ilmu Pendidikan Universitas Muhammadiyah Kendari. Waktu penelitian pada bulan Januari sampai April 2021. Subjek penelitian ini adalah mahasiswa PG-PAUD yang memprogramkan matakuliah statistik pendidikan dan dosen pengampu matakuliah statistik Pendidikan. Tahapan dan rencana penelitian dapat digambarkan dalam diagram alir sebagai berikut (Moleong, 2007).

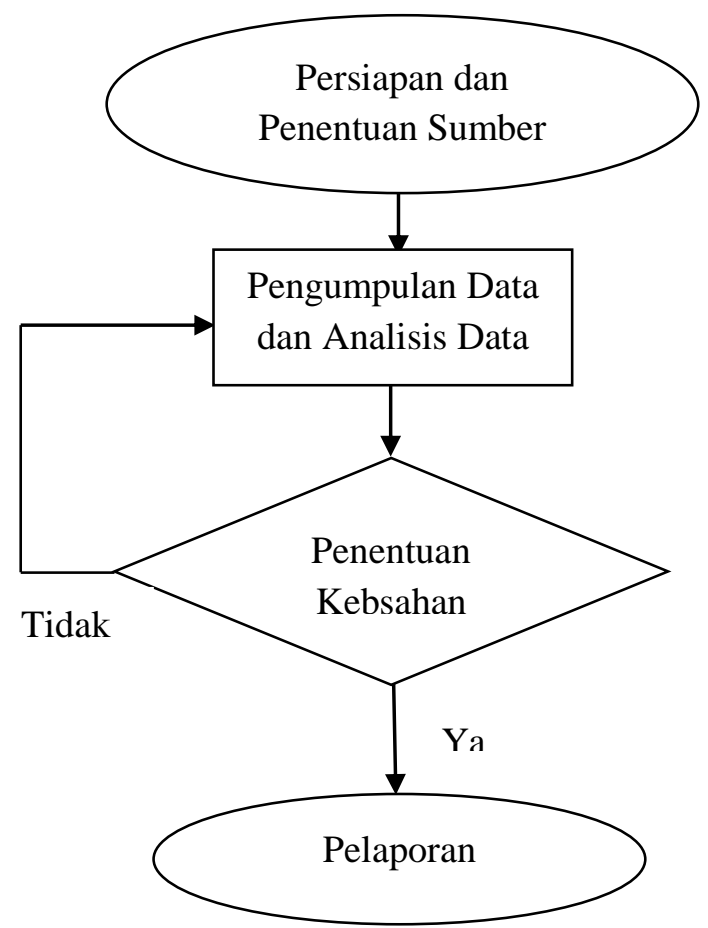

Gambar 2. Tahapan dan Rencana Penelitian

Teknik pengumpulan data dalam penelitian ini adalah observasi, wawancara dan dokumentasi.

Analisis data yang digunakan dalam penelitian ini, yaitu dilakukan dengan alur yang meliputi (1) reduksi data yaitu proses penyederhanaan atau proses seleksi data sesuai dengan kebutuhan peneliti. (2) penyajian data merupakan proses deskripsi dalam bentuk narasi dengan tujuan agar hasil penelitian dapat dipahamai lebih mudah. (3) Penarikan kesimpulan atau verifikasi, penarikan dan 
verifikasi data peneliti dilakukan agar data yang diperoleh mudah dan benarbenar dapat dipertanggungjawabkan (Miles \& Huberman, 1992).

\section{HASIL PENELITIAN DAN PEMBAHASAN}

\section{Hasil Penelitian}

\section{Analisis Hasil Belajar Statistik Pendidikan Pada Mahasiswa PG-PAUD Universitas Muhammadiyah Kendari}

Distribusi frekuensi data hasil belajar mahasiswa disajikan pada tabel berikut.

Tabel 1. Distribusi Frekuensi Hasil Belajar Mahasiswa

\begin{tabular}{|c|c|c|c|}
\hline $\begin{array}{c}\text { Kelas } \\
\text { Interval }\end{array}$ & Kategori & Frek (orang) & Persentase \\
\hline $\mathrm{Y}>86$ & Tinggi & 20 & $32.79 \%$ \\
\hline $78<\mathrm{Y} \leq 86$ & Sedang & 26 & $42.62 \%$ \\
\hline $\mathrm{Y} \leq 78$ & Rendah & 15 & $24.59 \%$ \\
\hline \multicolumn{2}{|c|}{ Total } & $\mathbf{6 1}$ & $100 \%$ \\
\hline
\end{tabular}

Berdasarkan Tabel 1, data dianalisis menggunakan konversi skala tiga diperoleh bahwa hasil belajar tinggi sebanyak 20 orang atau $32.79 \%$, hasil belajar sedang sebanyak 26 orang atau 42.62\%, dan hasil belajar rendah sebanyak 15 orang atau $24.59 \%$. Interval ini hanya berlaku pada populasi yang dianalisis, sehingga berdasarkan analisis ini dapat disimpulkan bahwa hasil belajar mahasiswa pada distribusi frekuensi berada pada kategori sedang. Jika ditampilkan dalam bentuk histogram dapat dilihat pada Gambar 3 berikut.

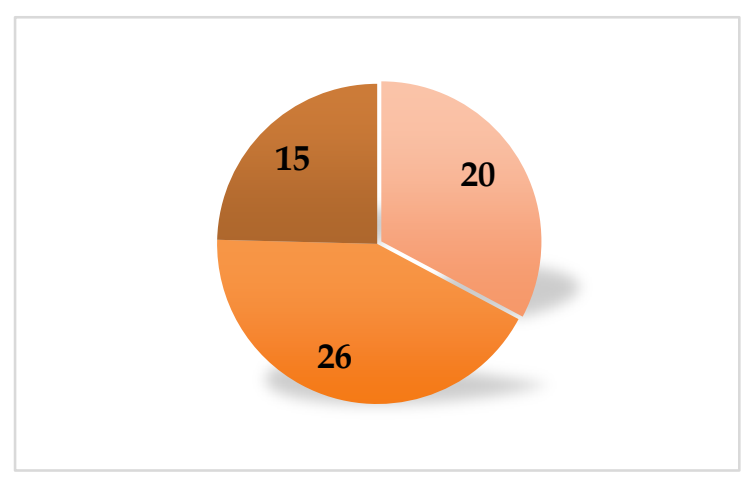

\section{Gambar 3. Grafik Distribusi Frekuensi Hasil Belajar Mahasiswa}

\section{Analisis Perencanaan Dosen Melalui Penerapan Media E-Lumak}

Pada Bulan Juli tahun 2020 seluruh dosen lingkup Universitas Muhammadiyah Kendari mengikuti pelatihan tenatang pembelajaran dengan menggunakan media e-lumak. Pelatihan itu memberikan pengetahuan tentang bagaimana seorang dosen membuat perencanaan dalam pembelajaran e-lumak sehingga nantinya dapat diaplikasikan dalam pembelajaran. Seperti yang disampaikan oleh dosen pengajar mata kuliah statistik pendidikan, Bapak Hendra Nelva Saputra sebagai berikut: "Membuat RPS pembelajaran full online terlebih 
dahulu, membuat desain pengorganisasian pembelajaran menggunakan elumak (Kamis, 27 Mei 2021)"

Hal ini senada dengan yang diungkapkan oleh Bapak Roni Amaludin sebagai berikut: "Pertama mendesain rencana pembelajaran semesternya (RPS), kemudian mengisi konten konten materi bentuk power point. Setelah itu evaluasi dan tugas pembelajaran (Senin, 24 Mei 2021)".

Berdasarkan hasil wawancara di atas dapat disimpulkan bahwa dosen telah merencakan pembelajaran mata kuliah statistik pendidikan melalui media elumak telah maksimal mulai dari merencanakan rencana pembelajaran semester (RPS), materi pembelajaran, alat evaluasi, daftar hadir mahasiswa, dan fitur-fitur lainnya yang terdapat di e-lumak.

\section{Analisis Pelaksanaan Pembelajaran dengan Menggunakan Media E-Lumak}

Peran pengajar dalam proses pembelajaran adalah melaksanakan pembelajaran dengan menggunakan platform e-lumak. Dosen harus melaksanakan pembelajaran yang telah direncanakan dengan baik. Platform elumak telah memiliki fitur-fitur yang sudah lengkap dalam pembelajaran. Seperti yang disampaikan oleh dosen pengajar mata kuliah statistik pendidikan, Bapak Roni Amaludin sebagai berikut: “Pembelajaran cukup baik karena antusiasme mahasiswa, akan tetapi ada beberapa kendala teknis dalam pembelajaran elumak, yaitu jaringan internet yang kurang stabil. (Senin, 24 Mei 2021)"

Selain Bapak Roni Amaludin, Bapak Hendra Nelva Saputra juga pengajar mata kuliah Statistik Pendidikan mengungkapkan sebagai berikut: "Ada beberapa hal yang harus diadakan pelatihan kembali sehingga pelaksanaan pembelajaran hanya menggunakan elumak, mengingat elumak sangat detil dan lengkap, sehingga tidak perlu ada platform lainnya (Kamis, 27 Mei 2021)"

Berdasarkan hasil wawancara di atas dapat disimpulkan bahwa pelaksanaan pembelajaran mata kuliah statistik pendidikan melalui media elumak cukup baik karena antusiasme mahasiswa, akan tetapi ada beberapa kendala teknis dalam pembelajaran e-lumak, yaitu jaringan internet yang kurang stabil.

\section{Analisis Evaluasi Hasil Belajar Mahasiswa Melalui Penerapan Pembelajaran Menggunakan Media E-Lumak}

Evaluasi pembelajaran bertujuan untuk menilai sejauh mana pelaksanaan pembelajaran yang telah dilakukan baik oleh dosen dan mahasiswa. Evaluasi hasil belajar mahasiwa setelah melaksanakan pembelajaran melalui media elumak untuk mengetahui daya serap mahasiswa terkait dengan materi yang telah diajarkan. Berdasarkan hasil wawancara dengan Bapak Hendra Nelva Saputra mengungkapkan bahwa: "Mahasiswa kurang termotivasi belajar menggunakan elumak dan hasil belajar Terkategori sedang (Kamis, 27 Mei 2021)"

Hal ini senada dengan yang diungkapkan oleh bapak Roni Amaludin sebagai berikut: "Hasil evaluasi baik dan jelas, maksudnya kita bisa mendapatkan semua nilai mahasiswa dari berbagai jenis evaluasi yang kita pilih dan gunakan 
saat awal pembelajaran dan Hasil belajar mahasiswa cukup baik walaupun tidak sebaik ketika tatap muka langsung (Senin, 24 Mei 2021)"

Berdasarkan hasil wawancara di atas dapat disimpulkan bahwa hasil evaluasi belajar mata kuliah statistik pendidikan melalui penggunaan media elumak sudah cukup baik. Secara garis besar hasil belajar mahasiswa berada pada kategori sedang.

\section{Kelebihan dan Kekurangan dalam Pembelajaran Melalui Media E-Lumak}

Pelaksanaan pembelajaran yang telah dilakukan oleh setiap dosen memiliki kelebihan dan kekurangan masing-masing. Media pembelajaran dengan menggunakan e-lumak memiliki kelebihan. Berdasarkan hasil wawancara kepada bapak Hendra Nelva Saputra mengungkapkan kelebihan dari media pembelajaran e-lumak bahwa sebagai berikut: "Sangat kompleks untuk pelaksanaan pembelajaran online (Kamis, 27 Mei 2021)" Hal ini senada dengan yang diungkapkan oleh bapak Roni Amaludin sebagai berikut: "Elumak memiliki kelebihan dibandingkan dengan yang lain disebabkan karena kita bisa melakukan semua hal dalam melaksanakan pembelajaran secara daring hanya dengan 1 aplikasi saja. Tidak perlu mengganti aplikasi lain (Senin, 24 Mei 2021)"

Berdasarkan hasil wawancara kepada bapak Hendra Nelva Saputra mengungkapkan kekurangan dari media pembelajaran e-lumak bahwa sebagai berikut: "Secara platform, tidak ada kekurangan. Tapi yang kurang adalah kemampuan individu dalam mengorganisasi pembelajaran menggunakan elumak. Oleh karena itu, perlu workshop lanjutan untuk dosen (Kamis, 27 Mei 2021)" Hal ini senada dengan yang diungkapkan oleh bapak Roni Amaludin sebagai berikut: "Kekurangannya adalah pada bagian server, kadang- kadang kita tidak bisa untuk login ke aplikasi karena server bermasalah atau maintenance (Senin, 24 Mei 2021)"

Berdasarkan hasil wawancara di atas dapat disimpulkan bahwa . kelebihan media e-lumak adalah sangat kompleks untuk pelaksanaan pembelajaran online dan Elumak memiliki kelebihan dibandingkan dengan yang lain disebabkan karena kita bisa melakukan semua hal dalam melaksanakan pembelajaran secara daring hanya dengan 1 aplikasi saja. Kekurangan media e-lumak dalam pembelajaran online adalah kemampuan individu dalam mengorganisasi pembelajaran menggunakan elumak dan server yang kurang stabil.

\section{Pembahasan}

Penerapan media pembelajaran berbasis e-lumak dalam pembelajaran statistik pendidikan pada mahasiswa PG-PAUD UM Kendari di Masa Pandemi Covid-19 sudah cukup efektif. Hal ini sejalan dengan pendapat Sihaan (2003), menyatakan bahwa salah satu pemanfaatan internet dalam dunia Pendidikan adalah pembelajaran dalam jaringan (on-line). Penelitian ini menggunakan pembelajaran e-lumak atau virtual learning. Media memiliki banyak konten yang sangat lengkap dalam pembelajaran online.

Proses pembelajaran yang berlangsung bahwa mahasiswa yang memiliki kemampuan untuk berargumen, mengkritisi pendapat yang disampaikan, dan 
berani mengkomunikasikan apa yang dipikirkan menjadi salah satu bentuk tercapainya kemampuan mahasiswa terkait dengan statistik. Media e-lumak sangat cocok digunakan dalam pembelajaran online selama masa pandemi covid19. Media e-lumak memiliki kelebihan dan kekurangan. Salah satu kelebihan dari media e-lumak adalah fitur-fitur yang sangat banyak dan lengkap, sedangkan kekurangan dari media e-lumak adalah server yang sering terganggu atau maintence.

Pada pembelajaran dengan menggunakan media elumak berbasis moodle dapat meningkatkan minat dan motivasi belajar mahasiswa. Strategi yang digunakan dosen adalah dengan merekam seluruh aktivitas pembelajaran mulai pembuka sampai dengan penutup. Media pembelajaran e-lumak berbasis moodle menyediakan berbagai aktivitas pembelajaran diantaranya assignment, bigbluebuttonbn, chat, choice, database, external tool, feedback, forum, glossary, lesson, quiz, scorm package, survey, wiki, dan workshop. Di samping itu, juga menyediakan sumber belajar di antaranya book, file, folder, IMS content package, label, page, dan URL.

Hal ini sejalan dengan Numiek (2011) menyatakan bahwa Pemanfaatan elearning dalam proses pembelajaran diharapkan bisa meningkatkan motivasi dan hasil belajar peserta didik. Selain itu, alur proses pembelajaran tidak harus berasal dari pendidik menuju peserta didik. Peserta didik bisa juga saling belajar dari sesama peserta didik lainnya. Selain itu, Herayanti (2017) menyatakan bahwa pengembangan media moodle dinyatakan 'layak' untuk digunakan demi mendukung proses pembelajaran dalam perkuliahan. Mahasiswa memberikan respon yang positif serta dapat meningkatkan motivasi belajar mereka.

\section{SIMPULAN}

Berdasarkan hasil analisis data dan pembahasan dapat disimpulkan sebagai berikut: 1) Media e-lumak sudah cukup baik dalam pembelajaran online pada mata kuliah statistik pendidikan di masa pandemi covid-19. Terdapat tiga tahapan dalam pembelajaran melalui media e-lumak antara lain tahap perencanaan, tahap pelaksanaan, dan tahap evaluasi. Pada tahap perencanaan, dosen telah merencakan pembelajaran mata kuliah statistik pendidikan melalui media e-lumak telah maksimal mulai dari merencanakan rencana pembelajaran semester (RPS), materi pembelajaran, alat evaluasi, daftar hadir mahasiswa, dan fitur-fitur lainnya yang terdapat di e-lumak. Pada tahap pelaksanaan, pelaksanaan pembelajaran mata kuliah statistik pendidikan melalui media elumak cukup baik karena antusiasme mahasiswa, akan tetapi ada beberapa kendala teknis dalam pembelajaran e-lumak, yaitu jaringan internet yang kurang stabil. Pada tahap evaluasi, hasil evaluasi belajar mata kuliah statistik pendidikan melalui penggunaan media e-lumak sudah cukup baik. Secara garis besar hasil belajar mahasiswa berada pada kategori sedang; 2) Kelebihan penerapan media pembelajaran berbasis e-lumak dalam pembelajaran statistik pendidikan pada mahasiswa PG-PAUD UM Kendari di Masa Pandemi Covid-19 adalah sangat kompleks untuk pelaksanaan pembelajaran online dan Elumak memiliki kelebihan dibandingkan dengan yang lain disebabkan karena kita bisa melakukan 
semua hal dalam melaksanakan pembelajaran secara daring hanya dengan 1 aplikasi saja. Kekurangan media e-lumak adalah kemampuan individu dalam mengorganisasi pembelajaran menggunakan elumak yang belum mumpuni dan server yang kurang stabil.

\section{UCAPAN TERIMA KASIH}

Terima kasih peneliti ucapkan kepada Universitas Muhammadiyah Kendari yang telah mendanai penelitian ini dan kepada LPPM Universitas Muhammadiyah Kendari yang telah membantu proses penelitian ini.

\section{DAFTAR PUSTAKA}

Bambang, Warsita. 2011. Landasan Teori dan Teknologi Informasi dalam Pengembangan Teknologi Pembelajaran. Jakarta: Teknodik

Chadrawati, Sri rahayu. 2010. Pemanfaatan E-Learning Dalam Pembelajaran. Jurnal Cakrawala Kependidikan 8 (2), 101-203. https://journal.uny.ac.id/index.php/cp

Hamalik, Oemar. 1994. Media Pendidikan. Bandung: Citra Adtya Bakti

Henich, R., Molenda, M., Russell, J.D., \& Smaldino, S.E. 1999. Instructional Media and Technology for Learning, Upper Saddle Rive, NJ: Pearson Education, Inc

Herayanti dkk. 2017. Pengembangan Media Pembelajaran Berbasis Moodle Pada Matakuliah Fisika Dasar. Jurnal Cakrawala Kependidikan, Nomor 2. https://journal.uny.ac.id/index.php/cp

Komariah, Aan dan Djam'an Satori. 2011. Metodologi Penelitian Kualitatif. Bandung : Alfabeta

Mahnun. Nunu. 2012. Media Pembelajaran (Kajian terhadap Langkah-langkah Pemilihan Media dan Implementasinya dalam Pembelajaran). Dalam Jurnal Pemikiran Islam; Vol. 37, No. 1: 27

Moleong, Lexy J. 2007. Metodologi Penelitian Kualitatif Edisi Revisi. Bandung: PT Remaja Rosdakarya

Miles, B Matthew \& A Michael Huberman. 1992. Analisis Data Kualitatif Buku Sumber Tentang Metode - Metode Baru. Jakarta: UT Press

Nasir, N. et al. (2020) 'Memaksimalkan Fitur "Breaking Rooms" Zoom Meeting pada Pendidikan Anak Usia Dini di Masa Pandemi Covid-19', Jurnal Obsesi: Jurnal Pendidikan Anak Usia Dini, 5(1), p. 611. doi: 10.31004/obsesi.v5i1.662.

Numiek, Sulistyo Hanum. 2011. Keefektifan E-Learning Sebagai Media Pembelajaran (Studi Evaluasi Model Pembelajaran E-Learning SMK Telkom Sandhy Putra Purwokerto. Jurnal Pendidikan, 3(1).

Purwandani, Indah. 2016. Pengembangan Elearning Berbasis Claroline untuk Pembelajaran PTIK. Prosiding KNIT 2 Vol 2 No 12016.

Purwono, Joni, dkk. 2014. Penggunaan Media Audio-Visual Pada Mata Pelajaran IImu Pengetahuan Alam Di Sekolah Menengah Pertama Negeri1 Pacitan. Dalam Jurnal Teknologi Pendidikan dan Pembelajaran Vol.2, No.2: 127 
Rothan \& Byrareddy. 2020. The epidemiology and pathogenesis of oronavirus disease (COVID-19) outbreak. J Autoimmun. Diakses Tanggal 3 Maret 2020. DOI: 10.1016/j.jaut.2020.102433

Siahaan, Sudirman. 2003. E-learning (Pembelajaran Elektronik) sebagai Salah satu Alternatif Kegiatan Pembelajaran. Jurnal Pendidikan dan Kebudayaan No. 042 Mei 2003. Jakarta Depdiknas

Sukardi \& Rozi, Fahrul. 2019. Pengaruh Model Pembelajaran Online Dilengkapi dengan Tutorial Terhadap Hasil belajar. Jurnal IImiah Penelitian dan Pembelajaran Informatika (JIPI). Volume 04 Nomor 02.

Surjono, Herman Dwi. 2011. Membangun Course E-Learning Berbasis Moodle. UNY Press: Yoyakarta

Wena, Made. (2009). Strategi Pembelajaran Inovatif Kontemporer. Jakarta: Bumi Aksara

Wijaya, Muksin. 2012. Pengembangan Model Pembelajaran e-Learning Berbasis Web dengan Prinsip e-Pedagogy dalam Meningkatkan Hasil Belajar. Jurnal Pendidikan Penabur - No.19/Tahun ke-11/Desember 2012

World Health Organizaton. 2020. Naming the coronavirus disease (COVID-19) and the virus that causes it. Diakses Tanggal 29 Maret 2020 . Disajikan di:htps://www.who.int/emergencies/diseases/novelcoronavirus-

2019/technical-guidance/naming-the-coronavirusdisease-(covid-2019)and-the-virus-that-causes-it. 